\title{
METAMODELS FOR NEW DESIGNS OF OUTER-ROTOR BRUSHLESS SYNCHRONOUS ELECTRIC MOTORS
}

\author{
J. Dirba, L. Lavrinovicha \\ Riga Technical University, \\ 1. Kronvalda Blvd., Riga, LV-1010, LATVIA \\ e-mail: janis.dirba@rtu.lv
}

\begin{abstract}
The authors consider the possibilities to synthesise metamodels for the analysis and optimisation of brushless synchronous motors. The metamodels are presented for new designs of the outer-rotor permanent magnet synchronous motor and the outer-rotor reluctance motor. The metamodels are synthesised based on the results obtained by the numerical calculations of magnetic field taking into account magnetic saturation. Analysis of the results for the motor magnetic field and tests of the metamodels at the selected and intermediate points shows that these can be synthesised with acceptable accuracy using numerical calculations instead of expensive real experiments.
\end{abstract}

Keywords: metamodels, brushless synchronous electric motor, magnetic field, numerical calculation.

\section{INTRODUCTION}

The urgency of electric energy saving increases the requirements to the electric power converters, especially to low-power electric motors [1]. The intensity of using the active materials for production of electric motors poses additional requirements as to the cost of electric motor. In this connection, brushless synchronous electric motors attract the most attention during the last several years.

Apart from that, it should be mentioned that the estimation of electric energy consumption by these motors and their total cost minimisation under modern conditions is impossible without a detailed analysis of the magnetic field. As known, the magnetic field of electric motors is rather complicated to calculate (traditionally with the finite element method [2]) owing to the magnetic saturation and overall complexity of magnetic circuit elements.

Today, the available software allows users to calculate the magnetic field of an electric motor at any configuration of its magnetic and ferromagnetic elements and any current value considering non-linear properties of the material [3]. However, each numerical calculation of magnetic field falls under a particular electric motor model at fixed magnetic circuit configuration, current value and material properties. Consequently, any change in the sizes and properties or in the current value of the motor magnetic circuit elements requires new numerical 
experiments (as compared with real experiments they have no random errors and are much cheaper) on the magnetic field of a motor, which would significantly complicate its optimisation. Therefore, the use of approximation models (metamodels [4]) that determine correlations between the results obtained by multiple numerical experiments is the best way to simplify solution of the optimisation task. Thus, the synthesis of a metamodel is directly associated with the efficient design of experiments [5].

Process of synthesising a metamodel consists of the following steps:

1. definition of the purpose of experiments (i.e. determination of the parameters that are the most sensitive to changes);

2. selection of the variable parameters (i.e. the motor parameters of interest) and the function under control;

3. identification of the changing bounds on each variable parameter and designing the plan of the variables' combinations for numerical experiments;

4. carrying out the numerical experiments and control of the function according to the designed plan of variables combinations;

5. synthesis of a metamodel based on the results obtained by numerical experiments;

6. testing the synthesised metamodel at the experimental and intermediate points.

Considering all the above mentioned, the aim of this work was to estimate the possibilities of synthesising the metamodels based on the results obtained by the magnetic field numerical calculations for analysing and optimisation of new brushless synchronous motor designs.

In the paper, the investigation results are presented for the permanent magnet synchronous motors (PMSMs) and the synchronous reluctance motors (SynRMs).

\section{NEW DESIGNS OF OUTER-ROTOR BRUSHLESS SYNCHRONOUS MOTOR AND NUMERICAL CALCULATION OF ITS MAGNETIC FIELD}

Under investigation in this paper are two types of the outer-rotor brushless synchronous motors (PMSM and SynRM). In particular, such motors are meant for application in 0.8-2 $\mathrm{kW}$ direct driven electric hand planers.

Each type of these motors has its own advantages and disadvantages. The use of modern permanent magnets to the excitation of PMSM allows reducing electric motor dimensions and increasing efficiency of the motor in comparison with other motor types in the same power range. However, such motors have also disadvantages: high cost of the modern permanent magnets, complexity of their mounting and production, and the fact that permanent magnets can lose their properties under hard operation conditions of the motor.

In turn, SynRM has no permanent magnets and special windings of excitation, so they have higher durability and lower cost in comparison with other types of motors. At the same time, mostly used SynRMs have a low electromagnetic torque per unit volume. With this disadvantage eliminated, such motors could become the most attractive for application in low-power electric tools. 
Therefore, the design, analysis and optimisation of new brushless synchronous motors are important for improvement of the electric motor efficiency.

The cross-section of four-pole PMSM under investigation is shown in Fig. 1. The motor consists of internal stator 1 with three-phase winding 2 in slots and four permanent magnets 3-6 that are mounted on the outer rotor 7 surface [6].

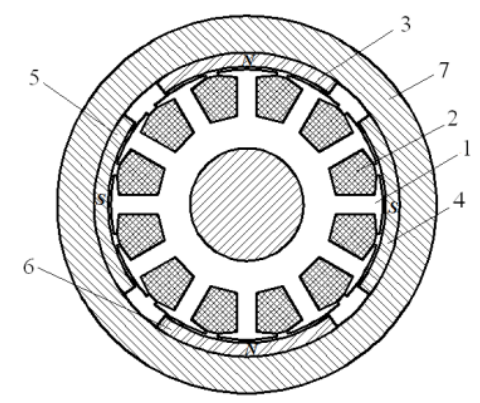

Fig.1. Cross-section of outer-rotor PMSM.

Figure 2 presents cross-section of the SynRM whose outer rotor is made of two mutually insulated ferromagnetic segment-shaped packages 3, 4 [7]. The stator is similar in design to that of PMSM.

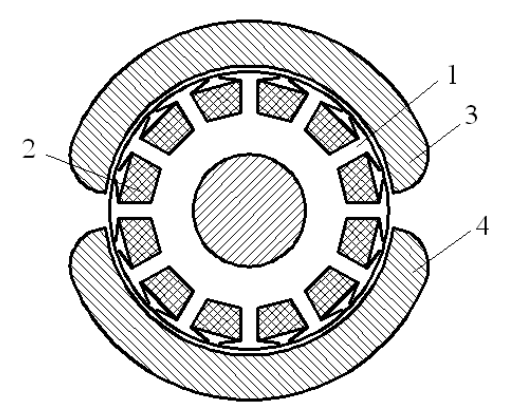

Fig.2. Cross-section of outer-rotor SynRM.

Numerical calculations of electric motor magnetic field (magnetic flux, flux density, electromagnetic torque) are realised using QuickField software [3].

The comparative results for the electromagnetic torque calculated using QuickField software and the experimentally obtained at a stalled rotor of PMSM are reported in [8]. Comparison made by the authors of [8] shows that the results obtained by numerical calculation of magnetic field are close to those of real experiment.

Taking into account that numerical experiments in contrast to real ones have no random errors and are much cheaper, there is no need to make a new model of the electric motor. Therefore, for metamodel synthesis the numerical calculations of magnetic field can be used.

Variable parameters whose influence on the electromagnetic parameters of investigated motors is the strongest were selected based on the results obtained for the magnetic field of brushless synchronous motors. The selected variable parameters are presented in Table 1. 
Variable parameters of the motors under investigation

\begin{tabular}{|l|c|c||l|c|c|}
\hline \multicolumn{2}{|c||}{ PMSM } & \multicolumn{3}{c|}{ SynRM } \\
\cline { 6 - 7 } Variable parameters & Variation range & Variable parameters & \multicolumn{2}{c|}{ Variation range } \\
\cline { 2 - 6 } & $\min$ & $\max$ & $\min$ & $\max$ \\
\hline $\begin{array}{l}\text { Permanent magnet } \\
\text { overlapping angle, } \alpha_{p m}, \\
\text { el.deg }\end{array}$ & 123 & 179 & $\begin{array}{l}\text { Segment-shaped package } \\
\text { overlapping angle, } \alpha_{s}, \text { el.deg }\end{array}$ & 121 & 175 \\
\hline $\begin{array}{l}\text { Permanent magnet thickness } \\
h_{p m}, \mathrm{~mm}\end{array}$ & 2.1 & 4.5 & $\begin{array}{l}\text { Segment-shaped packages } \\
\text { thickness } h_{s}, \text { mm }\end{array}$ & 4 & 7 \\
\hline $\begin{array}{l}\text { Permanent magnet residual } \\
\text { flux density Br, T }\end{array}$ & 0.3 & 1.3 & $\begin{array}{l}\text { Stator outer diameter } D_{s}, \\
\text { mm }\end{array}$ & 40 & 46 \\
\hline $\begin{array}{l}\text { Permanent magnet relative } \\
\text { permeability, } \mu \mathrm{r}\end{array}$ & 0.8 & 1.4 & & & \\
\hline Rotor yoke thickness $h_{r}, \mathrm{~mm}$ & 3.5 & 6.7 & & & \\
\hline
\end{tabular}

During realisation of the numerical experiments the selected variable PMSM parameters were varying, with the other motor parameters and material properties remaining invariable. Conversely, the stator tooth width, stator yoke thickness and the inner rotor diameter of SynRM were varying depending on the stator outer diameter at stator slot surface and air-gap being constant.

In compliance with known methods for designing experiments [5, 9], 81 and 49 experimental points (i.e. combinations of variable parameters) were selected for PMSM and SynRM, respectively, covering evenly the whole variation range under investigation.

To simplify the multiple magnetic field numerical calculations (made using QuickField software) and avoid occasional errors in designing models, a subprogram for QuickField was developed in Visual Basic included in MS Excel (for its detailed description see [10]). Users of the developed subprogram can input the required values of variable parameters into definite MS Excel cells, and it will automatically calculate the coordinates of the motor model and run the QuickField, where motor models are automatically designed and the magnetic field is calculated. The developed subprogram can easily be modified for any motor design, and, with the aid of QuickField, it will significantly simplify realisation of multiple numerical experiments.

\section{METHOD FOR METAMODEL SYNTHESIS}

For synthesising metamodels several methods exist [11], with the most useful being the method meeting simultaneously two mutually exclusive requirements - the accuracy and the efficiency [12]. Background for this method is described below.

Suppose that the variable parameters and the function under control are known and given in Table 2, where $x_{1}-x_{n}$ are variables, $k$ is the number of experiments and $y$ is the function under control. The task is to synthesise the following metamodel:

$$
y=f\left(x_{1}, x_{2}, \ldots x_{n}\right) .
$$


Representative table of variable parameters and function under control

\begin{tabular}{|c|c|c|c|c|c|}
\hline No. & $x_{1}$ & $x_{2}$ & $\ldots$ & $x_{n}$ & $y$ \\
\hline 1 & & & & & \\
\hline 2 & & & & & \\
\hline$\ldots$ & & & & & \\
\hline$k$ & & & & & \\
\hline
\end{tabular}

Using the method described in [12], first the bank of elementary functions is designed which would allow synthesis of a large number of metamodels such as

$$
y=A_{0}+\sum_{i=1}^{m} A_{i} f_{i}(\bar{x})
$$

where $\bar{x} \quad$ is the vector of variable parameters;

$f_{i}(\bar{x})$ is the elementary function selected from the bank;

$A_{i} \quad$ is the set of function coefficients;

$A_{0} \quad$ is a constant coefficient;

$m$ is the number of the elementary functions selected from the bank.

The elementary functions in the bank are described as

$$
f_{i}(\bar{x})=\prod_{j=1}^{n} \bar{x}_{j}
$$

where $n \quad$ is the number of variable parameters;

$a_{i j} \quad$ is the index of the $j$-th variable parameter in the $i$-th function

(a positive or a negative number).

To restrict the number of elementary functions in the bank, the maximum order for each parameter's totality is determined from the inequality:

$$
\sum_{j=1}^{n}\left|a_{i, j}\right| \leq K_{n}
$$

where $K_{n}$ is the maximum order that is preliminarily assumed for each parameter's totality.

The metamodel synthesis is realised in two stages. At the first stage perspective functions are selected from the elementary function bank. In compliance with the least squares method, the relevant coefficients are calculated for each elementary function. Then the common squared deviation:

$$
s_{i}=\sum_{j=1}^{k}\left(A_{i} f_{i}\left(\bar{x}_{j}\right)-y_{j}\right)^{2}
$$

is calculated for each function. 
The functions corresponding to the least squared deviation are selected as perspective ones. Then for each function we calculate the difference:

$$
\Delta_{j}=A_{0}+\sum_{i=1}^{p} A_{i} f_{i}\left(\bar{x}_{j}\right)-y_{j},
$$

where $p$ is the number of the perspective functions selected.

The initial metamodel is synthesised based on the selected perspective functions with the minimum difference. As a result, the obtained metamodel is too complicate to synthesise. Therefore, the second stage should be optimisation of the metamodel by its simplification. It is realised cutting down the elementary functions that exert weaker influence on the internal criteria $\sigma$. In this case, the monotonic wane of the internal criteria is obtained in the elimination process:

$$
\sigma=\sqrt{\frac{s}{k-p+1}} .
$$

The accuracy of the synthesised metamodel is defined by a correlation coefficient which is the relative average squared deviation:

$$
C=\left(1-\frac{\sigma}{\sigma_{0}}\right) \cdot 100 \%,
$$

where $\sigma_{0}=\sqrt{\sum_{i=1}^{k}\left(y_{i}-\frac{1}{k} \sum_{j=1}^{k} y_{i}\right)^{2} \cdot \frac{1}{k-1}}$.

To define the metamodel with the optimal relationship between accuracy and complexity, the elimination diagram is constructed (Fig. 3). The breaking point on this diagram determines the sought-for metamodel.

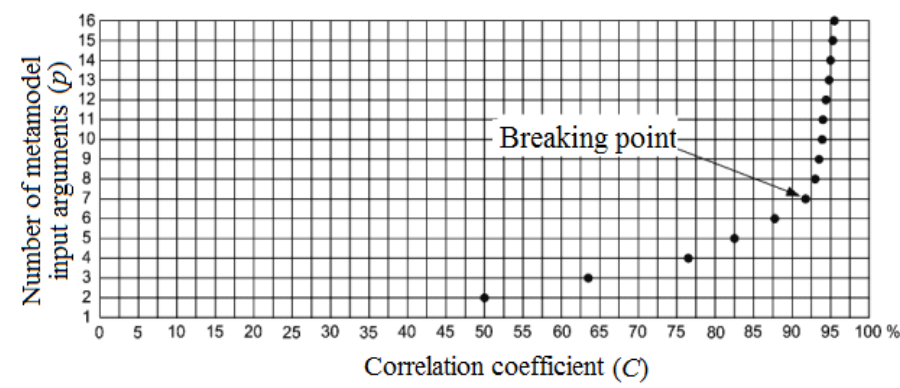

Fig.3. Elimination diagram of correlation coefficient

\section{METOMODELS FOR THE NEW OUTER-ROTOR BRUSHLESS SYNCHRONOUS MOTOR DESIGNS}

The metamodel for PMSM presented in Fig. 1 is synthesised by the method described above. According to this metamodel, the influence of variable parameters on the fundamental harmonic of magnetic flux $\Phi_{\delta 1}$ in the motor airgap can be described as 


$$
\begin{aligned}
& \Phi_{\delta 1}=\left(0.228-0.146 \alpha_{p m}^{*}-1.026 B_{r}^{* 2}+4.37 B_{r}^{*} h_{r y}^{*}+0.914 B_{r}^{*} h_{p m}^{*}-\right. \\
& -0.297 B_{r}^{*} \mu_{r}^{*}+0.4604 \alpha_{p m}^{*} h_{p m}^{*}-0.899 h_{r y}^{*} h_{p m}^{*}- \\
& \left.-1.461 B_{r}^{*} h_{r y}^{* 2}\right) \cdot l \cdot 10^{-3}(\mathrm{~Wb}),
\end{aligned}
$$

where $\alpha_{p m}^{*}=0.01 \alpha_{p m}$,

$$
\begin{aligned}
& B_{r}^{*}=B_{r}, \\
& \mu_{r}^{*}=\mu_{r}, \\
& h_{p m}^{*}=0.2 h_{p m}, \\
& h_{r y}^{*}=0.2 h_{r y} \text { are the reduced units of variable parameters, }
\end{aligned}
$$

and $\quad l$ is the active length of the motor.

Similarly, the metamodel that is synthesised to characterise the influence of variable parameters on the electromagnetic torque per unit volume $T / V$ of SynRM is:

$$
\begin{aligned}
& T / V=-2.964-1.366 \frac{1}{\alpha_{s}^{*}}+3.557 \frac{1}{h_{s}^{*}}+4.25 h_{s}^{*}-1.205 \alpha_{s}^{*}- \\
& -0.155 \frac{D_{s o}^{*}}{h_{s}^{*}} \cdot 10^{3} \quad\left(\mathrm{Nm} / \mathrm{m}^{3}\right),
\end{aligned}
$$

where

$$
\begin{aligned}
& \alpha_{s}^{*}=-1.667+0.01852 \alpha, h_{s}^{*}=0.4196+0.01787 h_{s}, \\
& D_{s o}^{*}=-6.167+0.167 D_{s o} \text { are the reduced units of variable parameters. }
\end{aligned}
$$

More detailed information on synthesising metamodels (9) and (10) is found in [13] and [14].

Testing of the presented metamodels demonstrates that the relative difference of the results from those obtained using software QuickField is $<8 \%$. Therefore, these metamodels can be applied for optimization of the motors under investigation.

\section{CONCLUSIONS}

Based on the results obtained, the following conclusions could be drawn:

1. The method for metamodel synthesis described in this paper can be useful for brushless synchronous electric motyors.

2. For synthesising metamodels the results obtained by numerical magnetic field calculations are recommended for use in order to avoid expensive real experiments.

3. The proposed metamodels can be applied for analysis and optimisation of the new brushless synchronous motor designs. 
This work has been supported by the European Social Fund within the project "Support for the implementation of doctoral studies at Riga Technical University" No. 2009/0144/1DP/1.1.2.1.2/09/IPIA/VIAA/005.

\section{REFERENCES}

1. Waide, P., \& Brunner, C.U. (2011). Energy-Efficiency Policy Opportunities for Electric Motor-Driven Systems. International Energy Agency (France).

2. Bianchi, N. (2005). Electrical Machine Analysis Using Finite Elements. CRC Press, Boca Raton, FL, Taylor \& Francis.

3. Tera Analysis (2010). QuickField. Finite Element Analysis System. Version 5.7. User's Guide (Denmark).

4. Ruichen Jin, Xiaoping Du, \& Wei Chen (2001). The use of metamodeling techniques for optimisation under uncertainty. In: ASME Design Automation Conf., Paper No. DAC21039.

5. Auziņš J., \& Janushevskis, A. (2007). Design and Analysis of Experiments. Riga: RTU (in Latvian).

6. Levin, N., Dirba, J., Brakanskis, U., Ketner, K., Orlova, S., \& Pugachev, V. (2011). Permanent magnet synchronous machine. Patent of Republic of Latvia, LV14335 B (in Latvian).

7. Pugachev, V., Dirba, J., Kukjane, L., Levin, N., \& Orlova, S. (2012). Synchronous reluctance motor. Patent of the Republic of Latvia, LV14418 (in Latvian).

8. Lavrinovicha, L., Dirba, J., \& Lavrinovich, N. (2013). Magnetostatic analysis of surface-mounted permanent magnet motor with external rotor for use in electric hand planer. In: Electric Power Engineering (EPE) Conf., Kouty nad Desnou: Technical University of Ostrava (Chech Republic).

9. Montgomery, D. C. (2005). Design and Analysis of Experiments ( $\left.5^{\text {th }} e d-n\right)$. New York: John Wiley \& Sons.

10. Kukjane, L., Brakanskis, U., \& Dirba, J. (2011). Visual Basic for application program for the automatic analysis of brushless DC motor magnetic field. In: 6th Intern. Conf. on Electrical and Control Technologies (ECT). Kaunas: Kaunas University of Technology, (Lithuania), 231-234.

11. Madala, H.R., \& Ivahnenko, A.G. (1994). Inductive Learning Algorithms for Complex Systems Modeling. London: CRC Press, ISBN 0-8493-4438-7.

12. Eglays, V. (1980). Regression model synthesis for the object on the basis of table data. Proceedings of the Latvian Academy of Sciences, Sect. of Natural and Tech. Sci. Vol. 4, 109-112.

13. Dirba, J., Lavrinovicha, L., Onzhevs, O., \& Vitolina, S. (2012). The influence of permanent magnet parameters on the effectiveness of brushless DC motor with outer rotor. In: $21^{\text {st }}$ Edition of the International. Symp. on Power Electronics, Electrical Drives, Automation and Motion (SPEEDAM), Sorrento (Italy), 718-723.

14. Lavrinovicha, L., Dobriyan, R., Onzevs, O. (2013). Metamodeling of the outer rotor synchronous reluctance motor. In: RTU $54^{\text {th }}$ Intern. Sci. Conf. on Power and Electrical Engineering, Riga (Latvia). 


\section{METAMODELU IZSTRĀDE JAUNAS KONSTRUKCIJAS BEZKONTAKTU SINHRONIEM DZINĒJIEM AR ĀRĒJO ROTORU}

J. Dirba, L. Lavrinoviča

Kopsavilkums

Rakstā ir apskatītas metamodeḷu iegūšanas iespējas to izmantošanai bezkontaktu sinhrono dzinēju analīzē un optimizācijā. Ir iegūti metamodeļi sinhronam dzinējam ar pastāvīgajiem magnētiem un reaktīvam dzinējam ar ārējo rotoru. Sintezēto metamodeļu iegūšanai izmantoti elektrisko dzinēju magnētiskā lauka skaitlisko aprēķinu rezultāti, ievērojot magnētiskās ķēdes piesātinājumu. Metamodel̦u pārbaude aprēķinu un starppunktos parādīja, ka to iegūšanai dārgo reālo eksperimentu vietā var izmantot magnētiskā lauka aprēķinu rezultātus.

29.10.2013. 